\title{
Analisis Mikrobia dan Organoleoptik Makanan Cair Instan Berbasis Pangan Lokal untuk Perbaikan Status Gizi Pasien
}

\section{Microbiology and Organoleptic Analysis of Local Food-based Enteral Nutrition Formulation for Patient Nutritional Status Improvement}

\author{
Susetyowati* , Lily Arsanti Lestari, Herni Astuti, Ismail Setyopranoto, Probosuseno
}

\begin{abstract}
ABSTRAK
Latar Belakang: Tingginya kebutuhan dukungan gizi pasien namun terbatasnya biaya penyediaan makanan enteral komersial mendorong Rumah Sakit (RS) untuk membuat formula enteral sendiri. Kekurangan dari formula enteral buatan RS diantaranya tidak praktis, tidak tahan lama, dan nilai gizi yang tidak terpantau. Labu kuning, ikan gabus dan tempe merupakan bahan pangan lokal yang terjangkau dengan kandungan protein dan antioksidan tinggi bermanfaat untuk perbaikan status gizi.

Tujan: Mengetahui angka total mikrobia (bakteri dan jamur) dan sifat organoleptik dari makanan cair instan berbasis pangan lokal.

Metode: Penelitian eksperimental dengan rancangan acak lengkap dilakukan pada Maret-Agustus 2018. Formula makanan cair memiliki 4 varian: vanilla, jahe, kayu manis, dan original. Analisis mikrobiologi pada formula bubuk dilakukan menggunakan metode angka lempeng total (ALT) untuk bakteri dan jamur. Pengujian sifat organoleptik pada formula yang sudah diseduh dilakukan oleh 80 panelis tidak terlatih dari anggota Yayasan Stroke Indonesia. Kriteria inklusi untuk panelis uji organoleptik antara lain bersedia menjadi panelis dengan mengisi informed consent, usia $\geq 19$ tahun. Uji organoleptik dengan 5 skala kesukaan berdasarkan aspek warna, aroma, rasa, tekstur, dan keseluruhan. Uji statistik menggunakan Kruskal Wallis untuk melihat perbedaan tingkat kesukaan dari tiap varian formula makanan cair.

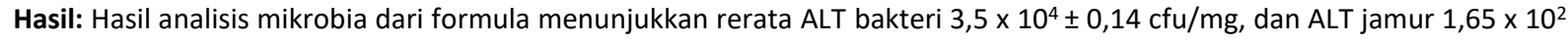
$\pm 0,21 \mathrm{cfu} / \mathrm{g}$. Terdapat perbedaan yang signifikan pada tingkat kesukaan varian formula makanan cair dari segi rasa, aroma, dan keseluruhan formula.

Kesimpulan: Uji mikrobia formula makanan cair masih dalam batas aman untuk dikonsumsi berdasarkan SNI 7388 : 2009 (5 x $10^{4}$ koloni/g). Responden paling menyukai varian rasa original dari aspek warna, rasa, dan tekstur, sedangkan secara keseluruhan dan aroma formula rasa vanilla yang paling disukai. Perbedaan rerata skor yang signifikan ditunjukkan pada varian rasa jahe, vanilla dan original dari segi rasa, serta varian rasa jahe dengan vanilla dari segi aroma dan keseluruhan.
\end{abstract}

Kata kunci: makanan cair, pangan lokal, mikrobiologi, organoleptik

\section{ABSTRACT}

Background: Every hospital has high demand of nutritional support for patient but limitation of hospital funding to get commercial enteral nutrition that may influence the hospital of making its own enteral nutrition. It has some weakness such as not ready to use, not durable, and unstandardized nutrition content. Pumpkin, fish cork, and tempeh are less costly local food which contain high protein and antioxidant that may lead nutritional status improvement.

Objectives: Determining total fungal count, total bacterial count and organoleptic properties of instant local food basedenteral nutrition.

Methods: Pure-experimental study with completely random design was conducted on March-August 2018. There are 4 flavors of the instant formula such as vanilla, ginger, cinnamon, and original. Total fungal count (TFC) and total bacterial count (TBC) were used for microbiological analysis. Organoleptic properties was evaluated by 80 panelists from Yayasan Stroke Indonesia. Inclusion criterias: aged 19-years or above and signing the informed consent. Organoleptic evaluation determined by 5 score of appearance, taste, texture, odour and overall formula. Statistical analysis used Kruskal Wallis to determine the difference of enteral nutrition acceptability for each flavor.

Results: Mean of TBC of local food based-enteral nutrition was $3.5 \times 10^{4} \pm 0.14 \mathrm{cfu} / \mathrm{mg}$ and mean of TFC was $1.65 \times 10^{2} \pm 0.21$ $c f u / g$. The acceptability of local food based-enteral nutrition was significantly different based on taste, odour, and overall aspect.

Conclusions: Based on microbiology analysis showed that local food based-enteral nutrition was desirable. Panelist liked original flavor most based on appearance, taste, and texture. While the vanilla flavor was liked the most based on the odour and overall aspect. The score of acceptability showed significantly different on ginger, vanilla, and original flavors based on taste, odour, and overall aspect. 
Keywords: enteral nutrition, local food, microbiology, organoleptic

\author{
*Koresponden: \\ Susetyowati \\ susetyowati@ugm.ac.id \\ Departemen Gizi Kesehatan, Fakultas Kedokteran, Kesehatan Masyarakat dan Keperawatan, Universitas Gadjah Mada \\ Jalan Farmako, Sekip Utara, Yogyakarta, Indonesia, 55281
}

\section{PENDAHULUAN}

Malnutrisi merupakan salah satu permasalahan yang dihadapi rumah sakit (RS) dan dapat timbul sejak sebelum dirawat yang disebabkan karena penyakitnya atau masukan zat gizi yang tidak cukup. Namun, tidak jarang pula malnutrisi ini timbul selama dirawat inap dan berlanjut hingga paska rawat.

Besarnya prevalensi malnutrisi pasien telah banyak ditemukan sejak tahun 1970-an, namun walaupun sudah banyak dilakukan upaya perawatan gizi pasien rawat inap, hingga tahun 2010-an besarnya prevalensi malnutrisi ini tidak banyak berubah yaitu berkisar antara $20-60 \%^{1}$. Di Indonesia, prevalensi malnutrisi pada pasien bedah dengan lama rawat inap panjang di RSUP Dr. Sardjito menemukan prevalensi malnutrisi sekitar $30-$ $50 \% 2,3$. Penelitian terbaru menunjukkan prevalensi malnutrisi pada pasien paska rawat sebesar $20-40 \% 4,5$.

Data menunjukkan sekitar $20-60 \%$ pasien datang ke RS sudah dalam kondisi malnutrisi sehingga bila tidak tertangani dengan baik selama perawatan di RS, malnutrisi akan berlanjut hingga pada kondisi paska rawat $^{6}$. Dalam jangka panjang, bila kondisi tersebut terus berlanjut akan memperburuk outcome gizi, yaitu besarnya risiko kembali dirawat di RS setelah dua minggu keluar $\mathrm{RS}^{6}$, durasi lama rawat yang panjang, peningkatan biaya rawat, hingga morbiditas dan mortalitas ${ }^{5}$.

Berkaitan dengan kondisi penyakitnya, pasien mengalami peningkatan katabolisme dalam tubuh baik sebelum, saat, dan setelah menjalani perawatan di RS7. Penatalaksanaan diet yang sesuai dengan pemenuhan kebutuhan tubuh perlu dilakukan untuk mencegah timbulnya morbiditas dari malnutrisi. Prinsip dasar pemenuhan gizi dengan memberikan makanan secara oral dan bila tidak terpenuhi, maka pemberian makanan cair atau enteral dapat diberikan. Makanan cair tidak hanya dapat diberikan selama pasien di rawat di rumah sakit saja, namun juga setelah pasien keluar dari rumah sakit, terutama pada pasien dengan risiko malnutrisi tinggi?.

Seiring dengan meningkatnya jumlah malnutrisi pasien berbagai RS mengalami peningkatan kebutuhan makanan enteral komersial tetapi, mengandung bahan pengawet kimia dan tidak sebanding dengan harga yang ditawarkan di pasaran sehingga anggaran menjadi membengkak $^{8}$. Oleh karena itu, sebagian besar RS berinisiatif membuat makanan enteral sendiri tetapi, kekurangan dari produk home made RS ini adalah nilai gizi yang tidak terstandar, proses pengolahan cukup lama, kurang praktis, dan tidak tahan lama ${ }^{9}$. Dengan melihat berbagai kekurangan tersebut, diciptakan suatu terobosan produk alternatif nutrisi enteral dengan berbagai keunggulan diantaranya menggunakan bahan baku pangan lokal yang mengandung nutraseutikal atau zat-zat fungsional yang bermanfaat untuk menunjang kesehatan tubuh ${ }^{10}$. Keunggulan lain adalah produk ini memiliki standar gizi yang sesuai dengan kebutuhan gizi pasien, aman, higienis, dan praktis.

Bahan baku pangan lokal yang digunakan diantaranya pati garut, ikan gabus, tempe kedelai lokal, dan labu kuning. Garut merupakan salah satu umbi yang berpotensi sebagai pangan fungsional dengan kandungan serat tinggi $(9,78 \%)$ dan indeks glikemik (IG) yang rendah yaitu $32^{11,12}$. Pati garut sendiri memiliki kandungan karbohidrat lebih tinggi $(98,74 \mathrm{~g})$ dibandingkan tepung garut $(85,2 \mathrm{~g})^{12}$. Sumber protein yang digunakan yaitu ikan gabus sebagai protein hewani dan tempe kedelai lokal sebagai sumber protein nabati. Ikan gabus mengandung protein $(25.5 \%)$ dan albumin $(6,22 \%)$ yang lebih tinggi daripada jenis ikan lainnya ${ }^{13}$. Tempe kedelai juga merupakan salah satu protein tinggi dari sumber nabati $(20,8 \mathrm{gram})^{13}$. Selain kelompok zat gizi makro, diperlukan sumber zat gizi mikro seperti vitamin, mineral, dan antioksidan. Labu kuning memiliki aktivitas antioksidan karena kandungan vitamin A sekitar $1569 \mathrm{mg}$ tiap 100 gram $^{13}$. Selain vitamin A, labu kuning juga mengandung beberapa kandungan mineral penting seperti kalsium, fosfor, dan zat besi.

Pada penelitian sebelumnya telah dilakukan uji organoleptik pada kelompok orang sehat dengan kriteria responden semi terlatih. Pada penelitian ini dilakukan uji angka total mikrobia (bakteri dan jamur) serta uji organoleptik pada kelompok sasaran yaitu pasien paska rawat dan masyarakat umum untuk melihat tingkat kesukaan formula yang telah dibuat.

\section{METODE}

Penelitian ini merupakan penelitian eksperimental dengan rancangan acak lengkap satu faktor, yaitu perlakukan variasi rasa sebagai bahan tambahan makanan dalam variasi produk makanan cair. Unit percobaan yang digunakan adalah formula makanan cair. Peubah yang diamati yaitu total mikroba dan sifat sensori formula meliputi warna, rasa, aroma, tekstur dan keseluruhan.

Penelitian ini diawali dengan proses pembuatan tepung dari bahan pangan lokal, yang meliputi penepungan labu kuning, ikan gabus, dan tempe kedelai, dilanjutkan dengan formulasi makanan cair, pengemasan makanan cair dalam sachet 1 takaran saji, dan uji kesukaan produk makanan cair. Proses pembuatan formula makanan cair hingga pengemasan dilakukan di Laboratorium Kuliner Gedung Gizi, FKKMK, UGM dan Laboratorium Pangan LIPI BTPBA Yogyakarta.

Penelitian dilaksanakan sejak bulan Maret hingga bulan Agustus 2018. Analisis mikrobiologi dalam formula dilaksanakan di Laboratorium Pangan 
Departemen Teknologi Pangan dan Hasil Pertanian, Fakultas Teknologi Pertanian UGM. Metode uji bakteri dan jamur yang dilakukan dengan cara perhitungan angka lempeng total mikroorganisme dari sampel bubuk formula makanan cair. Uji organoleptik dilakukan dengan memilih panelis berupa panelis tidak terlatih, yaitu pasien stroke paska perawatan beserta pendampingnya (keluarga) di Yayasan Stroke Indonesia (Yastroki) Yogyakarta dan dilaksanakan di Embung Tambakboyo, Yogyakarta. Berdasarkan syarat uji organoleptik pada panelis tidak terlatih, maka jumlah panelis yang dibutuhkan sebanyak 80 orang. Kriteria inklusi panelis sebagai berikut: bersedia menjadi panelis dengan mengisi informed consent, usia $\geq 19$ tahun, sedangkan kriteria eksklusi adalah adanya gangguan indera pembau dan pengecap serta alergi protein ikan dan susu. Uji organoleptik pada formula makanan cair yang sudah diseduh dilakukan dengan memberikan skoring pada warna, aroma, rasa, dan tektur dengan skala hedonik 1 : sangat tidak suka, 2: tidak suka, 3 : suka, 4: sangat suka.

Sampel yang digunakan dalam penelitian berupa formula makanan cair dengan 4 pilihan rasa yaitu rasa original, jahe, kayu manis, dan vanilla. Masingmasing panelis akan diberikan 4 sampel secara bergantian. Setiap sampel rasa panelis harus menilai sifat organoleptiknya dan menuliskan di formulir yang telah disediakan. Hasil data uji sensoris berupa tingkat kesukaan berupa data non-parametrik dianalisis dengan uji Kruskal-Wallis. Hasil uji sebelumnya yang bermakna statistik maka dilanjutkan dengan uji Mann-Whitney. Uji mikrobiologi dianalisis dengan nilai rata-rata hasil 2 kali pengukuran. Penelitian ini telah mendapatkan ijin dari komisi etik FKKMK UGM dengan nomor etik KE/FK/0575/EC/2018.

\section{HASIL DAN PEMBAHASAN}

Analisis mikrobia yang diuji dari makanan cair instan adalah total plate count (TPC) bakteri dan jamur saat produk masih dalam kemasan berbentuk bubuk. Hasil analisis mikrobia tersaji dalam tabel 1.

Tabel 1. Hasil analisis mikrobiologis formula

\begin{tabular}{ll}
\hline Uji ALT Mikroorganisme & Mean \pm SD \\
\hline TPC Bakteri (cfu / mg) & $3,5 \times 10^{4} \pm 0,14$ \\
TPC Jamur (cfu/g) & $1,65 \times 10^{2} \pm 0,21$
\end{tabular}

Bahan-bahan pangan yang digunakan dalam pembuatan formula enteral ini mudah rusak (perishable) dan mengandung zat gizi tinggi yang mana mikroorganisme dapat menggunakannya untuk tumbuh dan berkembang biak. Oleh karena itu perlu dilakukan pengujian tingkat mikrobia agar dapat mengetahui tingkat keamanan makanan tersebut ${ }^{14}$. Hasil TPC bakteri untuk makanan cair yang dibuat adalah 3,5 x 104 $\pm 0,14$ $\mathrm{cfu} / \mathrm{mg}$. Hasil TPC jamur produk 1,65 × 102. Berdasarkan SNI 7388 : 2009, batas maksimal total cemaran mikroba dengan metode pengukuran TPC/ALT (angka lempeng total) untuk susu bubuk dan sejenisnya yaitu $5 \times 10^{4}$ koloni/g. Hasil analisis pada Tabel 1 menunjukan bahwa TPC bakteri dan jamur produk masih dalam batas yang aman untuk dikonsumsi.

Lama penyimpanan dapat berpengaruh terhadap jumlah mikroba bahan makanan. Penelitian lain yang juga dilakukan pada formulasi tepung ikan gabus dan labu kuning menunjukkan hasil uji TPC secara signifikan terdapat peningkatan jumlah mikrobia seiring meningkatnya masa penyimpanan ${ }^{15}$. Selain itu, faktor lain yang dapat mempengaruhi jumlah mikroba dalam bahan makanan adalah $\mathrm{Aw}, \mathrm{pH}$, kandungan zat gizi bahan pangan, suhu penyimpanan dan pengolahan, ketersediaan oksigen pada makanan, serta proses pembuatan sampai makanan jadi ${ }^{15}$. Penelitian pada formula labu kuning dan telur bebek juga menunjukkan bahwa peningkatan lama simpan formula enteral berbanding lurus dengan jumlah TPC ${ }^{14}$. Pada lama simpan 1 jam jumlah TPC masih dalam batas normal yaitu 1,0 $x$ $10^{4} \mathrm{cfu} / \mathrm{g}$, namun pada lama simpan 2 dan 3 jam sudah melebihi batas normal ${ }^{14}$.

Tabel 2. Karakteristik responden tidak terlatih

\begin{tabular}{|c|c|c|}
\hline \multirow{2}{*}{ Karakteristik } & \multicolumn{2}{|c|}{ Frekuensi } \\
\hline & $\mathbf{n}$ & $\%$ \\
\hline Usia & & \\
\hline $\begin{array}{l}\text { a. Dewasa } \\
\text { (18-64 tahun) }\end{array}$ & 70 & 86,4 \\
\hline $\begin{array}{l}\text { b. Lansia } \\
\text { ( } \geq 65 \text { tahun) } \\
\text { Jenis Kelamin }\end{array}$ & 11 & 13,6 \\
\hline a. Laki-laki & 37 & 45,7 \\
\hline b. Perempuan & 44 & 54,3 \\
\hline
\end{tabular}

Dari penelitian ini diperoleh total responden tidak terlatih sebanyak 81 orang. Jumlah responden laki - laki dan perempuan hampir sebanding dan perbandingan ini diperoleh secara acak. Dari segi usia diketahui responden didominasi oleh kelompok usia dewasa (usia 19-64 tahun) sebanyak lebih dari $50 \%$ total responden.

Terlihat mayoritas responden sudah menyukai varian formula makanan cair. Hal ini bisa dilihat dari peniliain responden terhadap sifat organoleptik (warna, rasa, aroma, dan tekstur) lebih dari $50 \%$ dari total responden memberikan penilaian suka dan sangat suka. Dari segi warna, responden yang tidak menyukai warna produk hanya kurang dari seperempat dari total responden. Dari segi rasa, sudah lebih dari $50 \%$ total responden menyukai varian rasa original (skor 3 dan 4 sebanyak 67,9\%) dan vanilla (skor 3 dan 4 sebanyak $72,8 \%$ ). Pada formula makanan cair rasa kayu manis dan jahe terlihat responden yang menyukai rasa ini sebanding dengan jumlah responden yang tidak menyukai rasanya (skor 3 dan 4 jahe 49,3\%; kayu manis 50,6\%). Dari segi tekstur terlihat responden sudah menyukai tekstur dari semua varian rasa formula makanan cair (skor 3 dan 4 jahe $60,5 \%$, original $70,4 \%$, kayu manis $58,1 \%$, dan vanilla $65,4 \%$ ). Dari segi aroma, formula rasa vanilla mendapatkan skor tertinggi untuk aroma yang disukai (skor 3 dan 4) sebanyak 69,1\%, diikuti rasa original $(54,3 \%)$, kayu manis $(48,1 \%)$, dan jahe $(43,2 \%)$. Secara keseluruhan, responden menyukai semua varian formula makanan cair dengan varian yang paling disukai (terbanyak memperoleh skor 3 dan 4) yaitu vanilla (75,3\%). 
Tabel 3. Skor kesukaan setiap aspek penilaian

\begin{tabular}{|c|c|c|c|c|c|}
\hline & & \multicolumn{4}{|c|}{ Skala Kesukaan } \\
\hline & & $1(\%)$ & $2(\%)$ & $3(\%)$ & $4(\%)$ \\
\hline & & Sangat tidak suka & Tidak suka & Suka & Sangat suka \\
\hline \multicolumn{6}{|c|}{ Warna } \\
\hline a. & Jahe & 9,9 & 18,5 & 66,7 & 4,9 \\
\hline b. & Original & 2,5 & 19,8 & 66,7 & 11,1 \\
\hline c. & Kayu manis & 2,5 & 24,7 & 65,4 & 7,4 \\
\hline & Vanilla & 6,2 & 19,8 & 64,2 & 9,9 \\
\hline & Rasa & & & & \\
\hline a. & Jahe & 9,9 & 40,7 & 44,4 & 4,9 \\
\hline & Original & 0 & 32,1 & 54,3 & 13,6 \\
\hline c. & Kayu manis & 2,5 & 46,9 & 37 & 13,6 \\
\hline & Vanilla & 3,7 & 23,5 & 61,7 & 11,1 \\
\hline & Tekstur & & & & \\
\hline a. & Jahe & 6,2 & 33,3 & 58 & 2,5 \\
\hline b. & Original & 2,5 & 27,2 & 56,8 & 13,6 \\
\hline & Kayu manis & 2,5 & 39,5 & 51,9 & 6,2 \\
\hline & Vanilla & 6,2 & 28,4 & 58 & 7,4 \\
\hline & Aroma & & & & \\
\hline a. & Jahe & 8,6 & 48,1 & 38,3 & 4,9 \\
\hline b. & Original & 4,9 & 40,7 & 46,9 & 7,4 \\
\hline & Kayu manis & 7,4 & 44,4 & 39,5 & 8,6 \\
\hline & Vanilla & 1,2 & 29,6 & 55,5 & 13,6 \\
\hline & Keseluruhan & & & & \\
\hline a. & Jahe & 11,1 & 32,1 & 51,9 & 4,9 \\
\hline b. & Original & 1,2 & 28,4 & 59,2 & 11,1 \\
\hline & Kayu manis & 0 & 39,5 & 56,4 & 4,9 \\
\hline & Vanilla & 2,5 & 22,2 & 65,4 & 9,9 \\
\hline
\end{tabular}

Keterangan: Skor 1: sangat tidak suka, 2: tidak suka, 3: suka, 4: sangat suka

Uji organoleptik pada produk makanan cair berbasis pangan lokal menghasilkan 4 varian rasa formula makanan cair yang disukai responden. Tingkat kesukaan formula makanan cair dinilai dari 5 aspek, antara lain warna, rasa, aroma, tesktur, dan keseluruhan. Rerata skor yang berbeda signifikan ditunjukkan pada varian jahe dengan vanilla dan original. Varian yang paling disukai dari segi warna, rasa, dan tekstur yakni varian rasa original, dan varian yang paling tidak disukai yakni jahe. Dari segi aroma dan keseluruhan formula, responden paling menyukai varian rasa vanilla.

Uji organoleptik dilakukan pada empat parameter yaitu warna, aroma, rasa, dan tekstur karena suka atau tidaknya konsumen terhadap suatu produk dipengaruhi oleh warna, bau, rasa, dan rangsangan mulut ${ }^{16}$. Uji hedonik atau kesukaan berperan penting dalam pengembangan suatu produk dengan meminimalkan risiko dalam pengambilan keputusan. Panelis dapat mengidentifikasi sifat-sifat sensori yang akan membantu mendeskripsikan produk ${ }^{17}$

Pemilihan makanan dipengaruhi oleh penerimaan atribut dan kesesuaian untuk dimakan. Sebagian besar keputusan pemilihan berdasarkan kualitas panca indera. Penilaian sensori berhubungan dengan tanggapan konsumen terhadap rupa bentuk, aroma, citarasa, tekstur dan rasa sesudah dimakan tanpa mempertimbangkan label, harga dan keterangan lainnya ${ }^{18}$.

Makanan cair enteral termasuk kedalam kelompok produk likuid atau cair. Atribut sensori yang dinilai untuk produk yang tergolong ke dalam produk likuid yaitu terdiri dari warna, aroma, rasa dan tekstur ${ }^{19}$. Pengembangan atribut mutu yang sesuai untuk produk makanan cair enteral yaitu untuk tekstur terdiri dari viskositas dan kehalusan, aroma yang dinilai bau amis, bau tengik, bau harum, bau asam, untuk atribut rasa yaitu kemanisan, keasaman, kepahitan, creamy, dan cerha atau keruh untuk atribut warna ${ }^{20}$.

Tabel 4. Hasil uji komparasi varian formula dengan sifat organoleptik

\begin{tabular}{|c|c|c|c|c|c|c|c|c|c|c|}
\hline \multirow{2}{*}{ Varian } & \multicolumn{2}{|c|}{ Warna } & \multicolumn{2}{|c|}{ Rasa } & \multicolumn{2}{|c|}{ Tekstur } & \multicolumn{2}{|c|}{ Aroma } & \multicolumn{2}{|c|}{ Keseluruhan } \\
\hline & Skor & Ket & Skor & Ket & Skor & Ket & Skor & Ket & Skor & Ket \\
\hline Jahe & 3 & Suka & 2 & $\begin{array}{l}\text { Tidak } \\
\text { suka }\end{array}$ & 3 & Suka & 2 & $\begin{array}{l}\text { Tidak } \\
\text { suka }\end{array}$ & 3 & Suka \\
\hline Original & 3 & Suka & 3 & Suka & 3 & Suka & 3 & Suka & 3 & Suka \\
\hline Kayu Manis & 3 & Suka & 3 & Suka & 3 & Suka & 2 & $\begin{array}{l}\text { Tidak } \\
\text { Suka }\end{array}$ & 3 & Suka \\
\hline Vanilla & 3 & Suka & 3 & Suka & 3 & Suka & 3 & Suka & 3 & Suka \\
\hline$p$ & & & & 02* & & & & $02 *$ & & $0.008^{*}$ \\
\hline
\end{tabular}

Keterangan:

Rerata skor disajikan dalam bentuk median,

* menunjukkan hasil signifikan dengan uji Kruskal-Wallis 
Kesukaan konsumen terhadap produk pangan salah satunya dipengaruhi oleh atribut warna. Warna merupakan atribut organoleptik yang pertama dilihat oleh konsumen dalam membeli atau mengkonsumsi suatu produk ${ }^{14}$. Warna harus dapat mewakili citarasa produk. Atribut warna yang digunakan dalam penelitian ini yaitu cokelat cerah, berasal dari warna hasil campuran labu kuning, pati garut, dan tepung susu. Aroma juga merupakan salah satu faktor yang mempengaruhi penerimaan produk. Bau amis dan bau harum khas perisa (kayu manis, jahe, dan vanila) adalah beberapa atribut sensori yang dinilai dalam penelitian ini. Penelitian lain pada formulasi ikan lele, semakin tinggi konsentrasi tepung ikan lele maka aroma makanan cair semakin tidak disukai karena semakin amis ${ }^{21}$. Selain kandungan dari formula, suhu penyajian juga berpengaruh. Aroma amis semakin tercium jika makanan cair sudah dingin ${ }^{21}$.

Atribut lain yang dinilai dalam penelitian ini yakni rasa, dan tekstur yang dapat dinilai menggunakan indra pengecap (lidah). Rasa adalah tingkat kesukaan yang dapat diamati dengan lidah dikelompokkan menjadi 4 tingkat kesukaan yakni sangat tidak suka, tidak suka, suka, dan sangat suka. Hasil rerata tingkat kesukaan formula makanan cair menunjukkan responden sudah menyukai rasa dari setiap varian makanan cair. Sedangkan tekstur merupakan tingkat kehalusan formula makanan cair saat di dalam mulut maupun saat ditelan. Tekstur perlu disesuaikan dengan kenyamanan seseorang saat menelan formula makanan cair agar tidak merangsang tersedak. Makanan cair yang dibuat dalam penelitian ini sudah lolos pengayakan bahan dengan mesh 80 . Dari hasil uji organoleptik diketahui responden sudah menyukai tekstur dari seluruh varian formula dengan skor median 3 (suka). Penelitian formula makanan cair berbasis tepung ikan lele, semakin tinggi konsentrasi tepung ikan lele teksturnya semakin kental21. Hal ini disebabkan penambahan tepung lele pada makanan cair menyebabkan adanya endapan sehingga ketika diminum masih terdapat ampasnya ${ }^{21}$.

Tabel 5. Rerata tingkat kesukaan varian formula makanan cair

\begin{tabular}{lllcc}
\hline & \multicolumn{1}{c}{ Jahe } & Original & Kayu Manis & Vanilla \\
\hline Warna & 2,67 & $2,86^{*}$ & 2,78 & 2,78 \\
Rasa & $2,44^{\mathrm{ab}}$ & $2,81^{*} \mathrm{ab}$ & 2,62 & $2,81^{*} \mathrm{ab}$ \\
Tekstur & 2,57 & $2,81^{*}$ & 2,62 & 2,67 \\
Aroma & $2,40^{\mathrm{ab}}$ & 2,57 & 2,50 & $2,82^{*} \mathrm{ab}$ \\
Keseluruhan & $2,51^{\mathrm{ab}}$ & 2,81 & 2,66 & $2,84^{*} \mathrm{ab}$ \\
\hline
\end{tabular}

Keterangan:

* menunjukkan varian formula yang paling disukai responden berdasarkan rerata skor tertinggi

ab menunjukkan hasil signifikan untuk uji Mann-whitney

Penelitian lain pada formula berbahan dasar labu kuning dan tempe, penambahan jus jeruk sebagai media konsumsi formula dapat memperbaiki aroma, rasa, dan after taste yang pahit ${ }^{22}$. Hal ini karena flavour merupakan gabungan dari aroma dan rasa, sehingga aroma yang segar akan memberikan rasa yang lebih nikmat ${ }^{22}$. Rasa jus jeruk yang manis dan beraroma segar ini dapat menutupi after taste yang pahit ${ }^{22}$.

\section{KESIMPULAN}

Berdasarkan hasil uji mikrobia, angka lempeng total (ALT) untuk bakteri dan jamur formula makanan cair yang dibuat masih dalam batas aman untuk dikonsumsi berdasarkan SNI 7388 : 2009 (5 x 104 koloni/g). Berdasarkan uji organoleptik, varian yang paling disukai dari segi warna, rasa, dan tekstur yakni varian rasa original, dan varian yang paling tidak disukai yakni jahe. Dari segi aroma dan keseluruhan formula, responden paling menyukai varian rasa vanilla. Perlu pengujian lebih lanjut mengenai faktor - faktor yang mungkin akan meningkatkan angka lempeng total mikroorganisme dan mempengaruhi perubahan sifat organoleptik, seperti lama penyimpanan dan suhu ruang penyimpanan.

\section{ACKNOWLEDGEMENT}

Penulis mengucapkan terima kasih kepada Yayasan Stroke Indonesia yang telah bersedia dan berkontribusi menjadi responden dalam penelitian ini serta Kemenristekdikti yang telah mendanai penelitian ini melalui hibah Penelitian Pengembangan Unggulan Perguruan Tinggi tahun 2018.

\section{REFERENSI}

1. Jensen, G. L. et al. Adult Starvation and DiseaseRelated Malnutrition: A Proposal for Etiology-Based Diagnosis in the Clinical Practice Setting From the International Consensus Guideline Committee. J. Parenter. Enter. Nutr. 34, 156-159 (2010).

2. Susetyowati, Shabrina, A., Santika, P. D. \& Pramantara, I. D. P. Nutritional Status of Patients with Non-Communicable Diseases after Discharged from Hospital. Pakistan J. Nutr. 15, 480-485 (2016).

3. Susetyowati, Pramantara, D. P. \& Istutiningrum, D. Association of Malnutrition with Quality of Life, Mortality and Readmission Post Hospitalization in Patients with Non-Communicable Disease. Pakistan J. Nutr. 15, 771-776 (2016)

4. Susetyowati, Hadi, H., Hakimi, M. \& Asdie, A. H. Development, Validation and Reliability of the Simple Nutrition Screening Tool (SNST) for Adult Hospital Patient in Indonesia. Pakistan J. Nutr. 13, 157-163 (2014).

5. Mayasari, M., Susetyowati \& Lestariana, W. Simple Nutritional Screening Tool (SNST) Has Good Validity to Identify Risk of Malnutrition on Hospitalized Elderly Patients. Pakistan J. Nutr. 13, 573-578 (2014).

6. Mahakalkar, C. et al. Malnutrition in hospitalised patients; a real concern in surgical outcomes. Int. J. Res. Med. Sci. 2, 250-257 (2014). 
7. Young, A. M., Kidston, S., Banks, M. D., Mudge, A. M. \& Isenring, E. A. Malnutrition screening tools: Comparison against two validated nutrition assessment methods in older medical inpatients. Nutrition 29, 101-106 (2013).

8. Braunschweig, C., Gomez, S. \& Sheean, P. M. Impact of declines in nutritional status on outcomes in adult patients hospitalized for more than 7 days. Journal of the American Dietetic Association 100, 1316-1322 (2000).

9. Mosselman, M. J., Kruitwagen, C. L. J. J., Schuurmans, M. J. \& Hafsteinsdóttir, T. B. Malnutrition and Risk of Malnutrition in Patients With Stroke: Prevalence During Hospital Stay. J. Neurosci. Nurs. 45, 194-204 (2013).

10. Nilesh, M. R., Vilas, P. A., Ambadas, J. S. \& Nilesh, M. Formulation Development of Enteral Nutrition Products. Int. Res. J. Pharm. 2, 19-28 (2011).

11. Bastian, F., Ishak, E., Tawali, A. B. \& Bilang, M. Daya Terima dan Kandungan Zat Gizi Formula Tepung Tempe dengan Penambahan Semi Refined Carrageenan (SRC) dan Bubuk Kakao. J. Apl. Teknol. Pangan 2, 5-8 (2013).

12. Faridah, D. N., Fardiaz, D., Andarwulan, N. \& Sunarti, T. C. Karakteristik Sifat Fisikokimia Pati Garut (Maranta arundinaceae). Agritech 34, 14-21 (2014).

13. Sholihah, Z. Analisis Kandungan Zat Gizi dan Daya Terima Formula Makanan Enteral Berbasis Labu Kuning (Cucurbita moschata) dan Telur Bebek. (Universitas Diponegoro, 2014).

14. Pratiwi, L. E. \& Noer, E. R. Analisis Mutu Mikrobiologi dan Uji Viskositas Formula Enteral Berbasis Labu Kuning (Curcubita moschata) dan Telur Bebek. J. Nutr. Coll. 3, 951-957 (2014).
15. Danarsi, C. S. \& Noer, E. R. Pengaruh Lama Penyimpanan terhadap Mutu Mikrobiologi Makanan Pendamping Air Susu Ibu (MP-ASI) Bubur Instan dengan Substitusi Tepung Ikan Gabus dan Tepung Labu Kuning. J. Nutr. Coll. 5, 58-63 (2016).

16. Laksmi, R. T. Daya Ikat Air, pH dan Sifat Organoleptik Chicken Nugget yang Disubstitusi dengan Telur Rebus. Indones. J. Food Technol. 1, (2012).

17. Mervina, Kusharto, C. M. \& Marliyati, S. A. Formulasi Biskuit dengan Substitusi Tepung Ikan Lele Dumbo (Clarias gariepinus) dan Isolat Protein Kedelai (Glycine max) sebagai Makanan Potensial untuk Anak Balita Gizi Kurang. J. Teknol. dan Ind. Pangan 23, 9-16 (2012).

18. Sharma, R. Sensory Quality Aspect of Yogurt. Webinar (2013).

19. Setyaningsih, D., Apriyantono, A. \& Sari, M. P. Analisis Sensori untuk Industri Pangan dan Agro. (IPB Press, 2010).

20. Yusmarini \& Efendi, R. Evaluasi Mutu Soygurt yang dibuat dengan Penambahan Beberapa Jenis Gula. J. Natur Indones. 6, 104-110 (2004).

21. Huda, N. Formulasi Makanan Cair Alternatif Berbasis Tepung Ikan Lele (Clarias gariepinus) sebagai Sumber Protein. Skripsi, Institut Pertanian Bogor, Bogor. (Departemen Gizi Masyarakat Fakultas Ekologi Manusia, 2014).

22. Junita, D. Formulasi Bubuk Fungsional Berbasis Labu Kuning (Cucurbita moschata) dan Tempe untuk Penderita Diabetes. Tesis, Institut Pertanian Bogor, Bogor. (Sekolah Pascasarjana, 2017). 